\title{
Tethering (Arene)Ru(II) Acylpyrazolones Decorated with Long Aliphatic Chains to Polystyrene Surfaces Provides Potent Antibacterial Plastics
}

\author{
Corrado Di Nicola ${ }^{1} * \mathbb{C}^{0}$, Fabio Marchetti ${ }^{1}\left(\mathbb{D}\right.$, Riccardo Pettinari $^{2}$, Alessia Tombesi $^{1}$, \\ Claudio Pettinari ${ }^{2}$, Iolanda Grappasonni ${ }^{2}$, Paul J. Dyson ${ }^{3}$ and Stefania Scuri ${ }^{2, *}$ \\ 1 School of Science and Technology, Chemistry Section, University of Camerino, Via S. Agostino 1, \\ 62032 Camerino Macerata, Italy; fabio.marchetti@unicam.it (F.M.); alessia.tombesi@unicam.it (A.T.) \\ 2 School of Pharmacy, Chemistry Section, University of Camerino, Via S. Agostino 1, \\ 62032 Camerino Macerata, Italy; riccardo.pettinari@unicam.it (R.P.); claudio.pettinari@unicam.it (C.P.); \\ iolanda.grappasonni@unicam.it (I.G.) \\ 3 Institut des Sciences et Ingénierie Chimiques, École Polytechnique Fédérale de Lausanne (EPFL), \\ 1015 Lausanne, Switzerland; paul.dyson@epfl.ch \\ * Correspondence: corrado.dinicola@unicam.it (C.D.N.); stefania.scuri@unicam.it (S.S.); \\ Tel.: +39-0737-402338 (C.D.N.); +39-0737-402020 (S.S.)
}

Received: 5 December 2019; Accepted: 19 January 2020; Published: 22 January 2020

Abstract: The acylpyrazolone proligands $\mathrm{HQ}^{\mathrm{R}}\left(\mathrm{HQ}^{\mathrm{R}}\right.$ in general, in detail: $\mathrm{HQ}^{\mathrm{Cy}}$ $=$ 1-phenyl-3-methyl-4-carbonylcyclohexyl-5-pyrazolone, 4-C(O)-phenyl, $\quad \mathrm{HQ}^{\mathrm{Ph}}=$ 1-phenyl-3-methyl-4-benzoyl-5-pyrazolone, $\mathrm{HQ}^{\mathrm{C} 17}=$ 1-phenyl-3-methyl-4-stearoyl-5-pyrazolone, $\mathrm{HQ}^{\mathrm{C17}, \mathrm{Ph}}=1$-phenyl-3-stearyl-4-benzoyl-5-pyrazolone) were synthesized and reacted with (arene) $\mathrm{Ru}(\mathrm{II})$ acceptors affording complexes $\left[(\right.$ arene $\left.) \mathrm{Ru}\left(\mathrm{Q}^{\mathrm{R}}\right) \mathrm{Cl}\right]$ (arene = cymene $(\mathrm{cym})$ or hexamethylbenzene $(\mathrm{hmb})$ ). The complexes were characterized by elemental analyses, thermogravimetric analysis-Differntial Thermal Analysis (TGA-DTA), IR spectroscopy, ESI-MS and ${ }^{1} \mathrm{H}$, and ${ }^{13} \mathrm{C}$ NMR spectroscopy. Complexes [(arene) $\mathrm{Ru}\left(\mathrm{Q}^{\mathrm{R}}\right) \mathrm{Cl}$ ] where $\mathrm{Q}^{\mathrm{R}}=\mathrm{Q}^{\mathrm{C} 17}$ and $\mathrm{Q}^{\mathrm{C17}, \mathrm{Ph}}$, due to the long aliphatic chain in the ligand, afford nanometric dispersions in methanol via self-assembly into micellar aggregates of dimensions 50-200 nm. The antibacterial activity of the complexes was established against Escherichia coli and Staphylococcus aureus, those containing the ligands with a long aliphatic chain being the most effective. The complexes were immobilized on polystyrene by a simple procedure, and the resulting composite materials showed to be very effective against $E$. coli and S. aureus.

Keywords: bioorganometallic chemistry; Ruthenium(II) complexes; acylpyrazolones; nanoformulation; tethering on polyethylene and polystyrene; antibacterial composite materials

\section{Introduction}

A wide range of ruthenium-based complexes display promising properties for cancer chemotherapy and have emerged as a potential alternative to the platinum-derived therapeutics [1-3]. In recent years $\mathrm{Ru}(\mathrm{III})$ and $\mathrm{Ru}(\mathrm{II})$ have successfully entered clinical trials [4-10] and their mechanisms of anticancer action have been investigated [11-13]. However, ruthenium complexes possess additional interesting medicinal properties, such as antiparasitic [14] and antibacterial [15-17] activity. In this respect, a general approach based on tethering antibacterial agents such as deferoxamine B to (arene) $\mathrm{Ru}(\mathrm{II})$-platforms has been proposed [18]. The incorporation of antimicrobials within plastic appliances and surfaces has attracted over the last few years a great deal of research and development attention because of widespread concerns at all levels in safety and hygiene [19]. The types of polymeric systems with antimicrobial activity can be divided into four main groups: (a) polymers with intrinsic 
antimicrobial activity; (b) polymers that are chemically or physically modified to covalently incorporate an antimicrobial function; (c) polymers containing organic antimicrobial substances non covalently linked to the matrix; (d) polymers containing inorganic antimicrobial substances non covalently linked to the matrix [20]. The current industrial production of antimicrobial plastics is mainly based on the use of silver-based antimicrobial additives, especially silver nanoparticles. However, recent studies seem to indicate a potential toxicity to humans deriving from the use and massive release of metal nanoparticles into the environment, and alternative technological solutions to the use of nanoparticles are the subject of numerous studies [21,22]. Our interests are devoted to the development of sustainable methodologies that afford scalable functional materials endowed with antimicrobial activity [23-25]. We have recently reported the preparation of composite materials formed by loading (cymene) $\mathrm{Ru}(\mathrm{II})$ curcumin complexes, previously reported to be potent antitumor agents [26], on porous carbon adsorbents, which display efficient antibacterial activity [27]. These features are relevant to the use of such carbon composites in air filters for some specific applications in the food and pharmaceutical industries, such as in air conditioning equipment, especially for hospitals, in operating rooms, [28] etc. Previously we reported several (arene)Ru(II) complexes [29-32] with acylpyrazolone ligands, which are $\beta$-diketones with a pyrazole fused to the chelating arms, and they exhibit anticancer activity [33-35]. The combination of both the $\mathrm{Q}^{\mathrm{C} 17}\left(\mathrm{HQ}^{\mathrm{C} 17}=1\right.$-phenyl-3-methyl-4-stearoyl-5-pyrazolone, see Chart 1) and PTA (PTA = 1,3,5-Triaza-7-phosphaadamantane) ligands on the same (arene)Ru(II) scaffold resulted in highly cytotoxic compounds with a potency comparable to cisplatin in human ovarian A2780 cancer cells, indeed being equally cytotoxic to both the A2780 and the cisplatin-resistant A2780cisR cancer cell lines and similar to other (arene) $\mathrm{Ru}(\mathrm{II})$ complexes bearing both a PTA ligand and a long hydrophobic chain [36]. Due to their tendency to release the $\mathrm{Q}^{\mathrm{C} 17}$ and form the same species as RAPTA-C inside a cell, their strong cytotoxicity is particularly interesting, as they can be considered as prodrugs able to generate RAPTA-C, which is essentially not cytotoxic, in part due to limited cellular uptake [37].

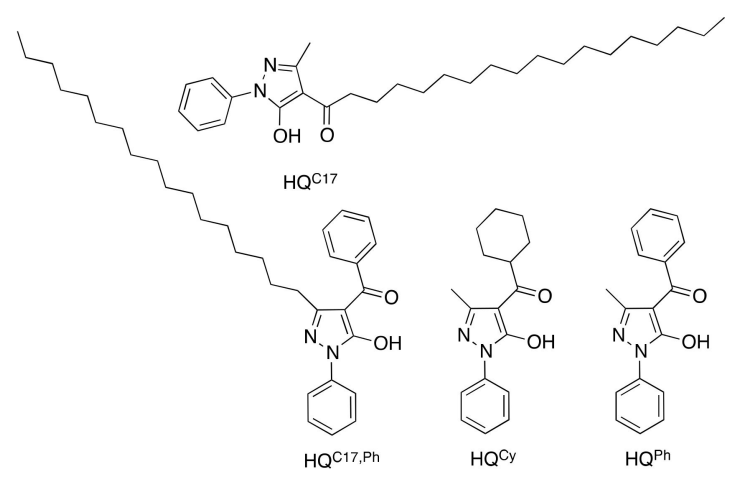

Chart 1. $\mathrm{HQ}^{\mathrm{R}}$ proligands used in this work.

Herein, we extend our nascent studies to the synthesis of a new proligand HQC17,Ph bearing a long aliphatic chain in the three-position of the pyrazole, usually occupied by a methyl group (Chart 1) and the corresponding (arene)Ru(II) derivatives (arene = cymene and hexamethylbenzene). All substances were subjected to microbiological tests against Escherichia coli and Staphylococcus aureus. For comparative purposes, the previously reported (arene) $\mathrm{Ru}(\mathrm{II})$ complexes with other $\mathrm{QR}$ ligands (Chart 1) were also screened against these organisms. Additionally, complexes containing ligands $\mathrm{Q}^{\mathrm{C} 17}$ and $\mathrm{Q}^{\mathrm{Ph}, \mathrm{C} 17}$ showed amphipathic behavior due to the long hydrophobic chain present in their structures. this structural feature was exploited to immobilize the complexes onto a polystyrene surface using a simple procedure, affording antibacterial composite plastics.

Polystyrene was chosen in this study as it is a well-known thermoplastic polymer, the scale of its production being several million tonnes per year, which can be solid or foamed, widely used for many applications including protective packaging, bottles, trays, tumblers, disposable cutlery, containers, lids, etc. etc. due to its flexibility, easy processability, thermal stability, environmental recyclability, 
and inexpensive properties [38]. In consideration of this variety of possible applications, polystyrene is a suitable polymer to be tested for the preparation of new antimicrobial composite materials through a surface treatment aimed at anchoring antimicrobial additives. Additionally, polystyrene presents a good solubility in some organic solvents, such as acetone which was advantageously used in the preparation of our composite materials.

\section{Results}

\subsection{Synthesis and Characterization of the $H Q^{R}$ Proligands}

Proligands $\mathrm{HQ}^{\mathrm{Ph}}, \mathrm{HQ}^{\mathrm{Cy}}$, and $\mathrm{HQ}^{\mathrm{C} 17}$ were prepared following a published procedure [34]. Proligand $\mathrm{HQ}^{\mathrm{Ph}, \mathrm{C} 17}$ was synthesized for the first time following a two-step procedure, by preparing the precursor 3-heptadecyl-1-phenyl-1H-pyrazol-5(4H)-one ( $\mathrm{HP}^{\mathrm{Ph}, \mathrm{C} 17}$ in Scheme 1$)$ through the condensation of phenylhydrazine and ethyl stearoylacetate in methanol. The precursor was then acylated at the C-4 position of the pyrazole ring by reaction with benzoyl chloride in basic (calcium hydroxide) [39] dioxane at reflux. Subsequent acidification afforded the proligand $\left(\mathrm{HQ}^{\mathrm{Ph}, \mathrm{C} 17}\right.$ in Scheme 1) in high yield as a pale pink solid powder that is insoluble in water.

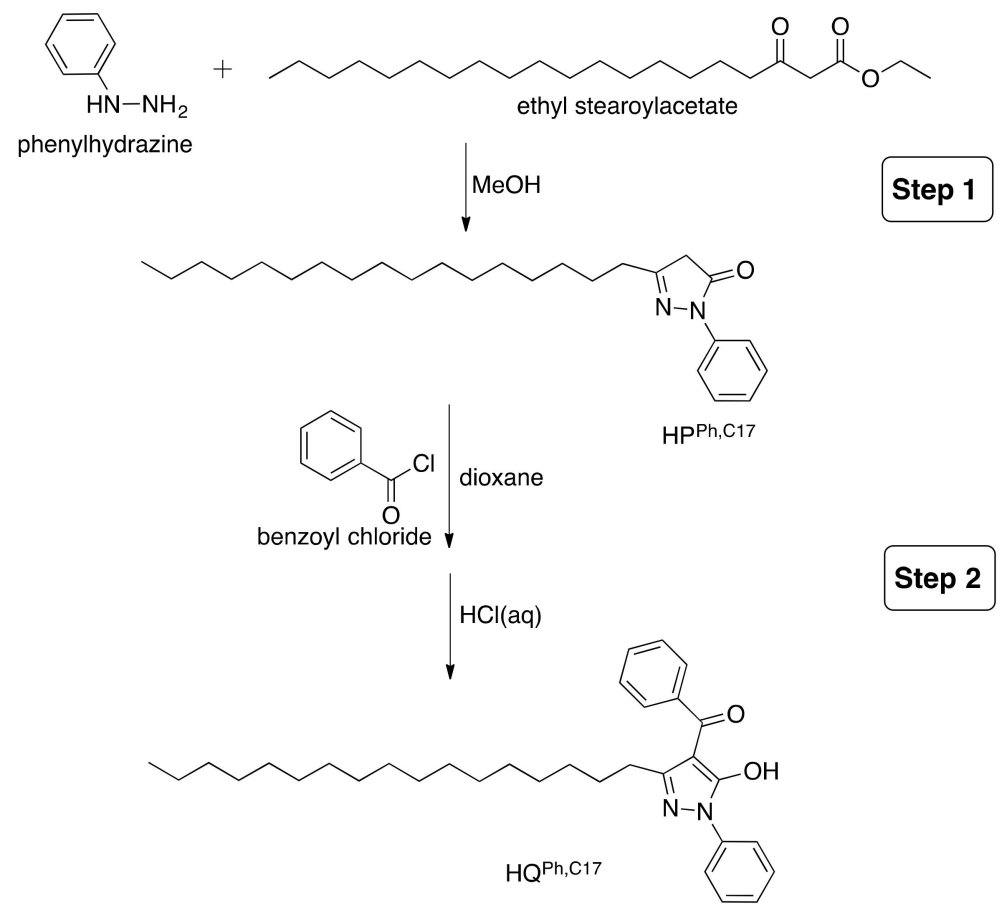

Scheme 1. Synthetic procedure for proligand $\mathrm{HQ}^{\mathrm{Ph}, \mathrm{C} 17}$.

The $\mathrm{HQ}^{\mathrm{Ph}, \mathrm{C} 17}$ proligand is a low melting solid, soluble in chlorinated solvents, acetone, DMF, diethyl ether and n-hexane, and slightly soluble in hot ethanol. The broadband between 2500 and $2800 \mathrm{~cm}^{-1}$ in the IR spectrum indicates the prevalence of the keto-enol tautomeric form in the solid-state, with strong adsorptions at 2921 and $2852 \mathrm{~cm}^{-1}$ due to the long aliphatic chain at $\mathrm{C} 3$ position of pyrazolone ring and at 1599 and $1546 \mathrm{~cm}^{-1}$ due to $v(\mathrm{C}=\mathrm{O})$ stretching modes. The ${ }^{1} \mathrm{H}$ and ${ }^{13} \mathrm{C}$ NMR spectra recorded in $\mathrm{CDCl}_{3}$ display all the expected proton and carbon resonances for the phenyl rings and those of the aliphatic chain in position 3 of the pyrazolone ring.

\subsection{Synthesis and Characterization Complexes 1-8}

Complexes 1-8 were prepared by the reaction of proligands $\mathrm{HQ}^{\mathrm{R}}$ with the appropriate [(arene) $\left.\mathrm{RuCl}_{2}\right]_{2}$ dimers (where arene is cymene (cym) or hexamethylbenzene $\left.(\mathrm{hmb})\right)$ in methanol in the presence of $\mathrm{KOH}$ (Scheme 2). 


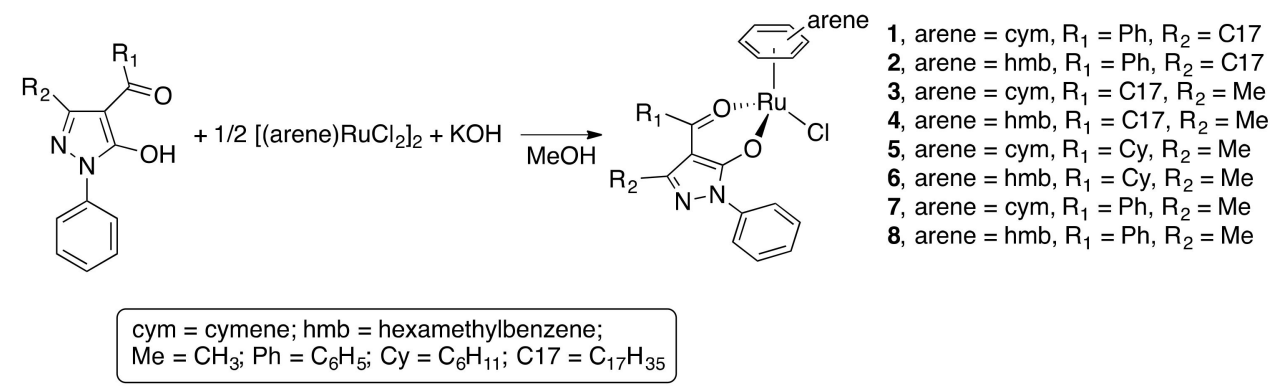

Scheme 2. Synthetic procedure for complexes 1-8.

Complexes 3-8 were previously reported and characterized [31,32], whereas 1 and 2 are new. Complex 2 is a low melting solid, whereas 1 is a viscous liquid. Both are highly soluble in alcohols, acetone, acetonitrile, DMSO, DMF, diethyl ether, $n$-hexane, and chlorinated solvents. The IR spectra of 1 and 2 display a typical shift of the $v(\mathrm{C}=\mathrm{O})$ stretches, with respect to that observed for the free neutral ligand, in accordance with the coordination of the $\mathrm{O}_{2}$-chelating moiety to the ruthenium(II) centers. Additional bands in the far-IR region appear upon coordination, and those at around 450 and $280 \mathrm{~cm}^{-1}$ were assigned to $v(\mathrm{Ru}-\mathrm{O})$, and $v(\mathrm{R}-\mathrm{Cl})$ stretches (Figure S1 in Supplementary) $[29,31,32,40]$. The ${ }^{1} \mathrm{H}$ and ${ }^{13} \mathrm{C}$ NMR spectra of 1 and 2 were recorded in $\mathrm{CDCl}_{3}$ and display a set of signals due to the $\mathrm{Q}^{\mathrm{Ph}, \mathrm{C} 17}$ ligand, slightly shifted in frequency in comparison with the free proligand (Figures S2-S7 in Supplementary), the typical $\mathrm{AA}^{\prime} \mathrm{XX}^{\prime}$ pattern of the cymene protons in 1 and a unique resonance for the $\mathrm{CH}_{3}$ protons in hexamethylbenzene in 2. The proton and carbon assignments were made on the basis of previous studies on analogous complexes $[29,31,32,40]$. The positive ESI-MS spectra of 1 and 2 show a peak corresponding to the $\left[(\text { arene }) \mathrm{Ru}\left(\mathrm{Q}^{\mathrm{Ph}, \mathrm{C17}}\right)\right]^{+}$ion arising from the detachment of chloride. Both complexes undergo progressive decomposition from 180 to $850{ }^{\circ} \mathrm{C}$, as found by thermogravimetric analysis (TGA) analysis.

\subsection{Microbiological Study on Complexes 1-8 and Proligands $H Q^{R}$}

A time-kill kinetics assay was used to analyze the antibacterial activity of (arene)Ru(II) complexes 1-8 and proligands $\mathrm{HQ}^{\mathrm{R}}$ against E. coli and S. aureus, with the growth inhibition evaluated in terms of log-reduction. The results are presented by grouping complexes $1-4$, complexes $5-8$ and the proligands separately (Figure 1). Among complexes 1-4, characterized by the presence of acylpyrazolones with a long aliphatic chain in either the 3 or 4 position of the pyrazolone ring, complex 2, with hmb and $\mathrm{Q}^{\mathrm{Ph}, \mathrm{C} 17}$ ligands bound to the $\mathrm{Ru}(\mathrm{II})$ ion, showed the highest efficacy against both Gram- E. coli and Gram+ S. aureus, achieving a complete inhibition of E. coli and S. aureus growth just after $4 \mathrm{~h}$ (Figure 1a,b). This antibacterial activity is the highest among all complexes (1-8), and corresponds to a log-reduction higher than 3 log units, which implies strong antibacterial activity of complex 2 . Complex 3, bearing cymene and $\mathrm{Q}^{\mathrm{C} 17}$ ligands on the $\mathrm{Ru}(\mathrm{II})$ fragment, also showed a good efficacy, in particular against $E$. coli. Significant antibacterial activity (1-3 $\log$ reduction) was shown by complex 3 after $4 \mathrm{~h}$, achieving a log reduction higher than 3 after $16 \mathrm{~h}$, corresponding to a strong activity. However, complex 3 showed a significant reduction against $S$. aureus only after $24 \mathrm{~h}$. The growth of E. coli, in the presence of complex 3, resulted on a log reduction of 4.90, which represents a strong antibacterial activity. Complex 4 , with $\mathrm{hmb}$ and $\mathrm{Q}^{\mathrm{C} 17}$ ligands coordinated to the $\mathrm{Ru}(\mathrm{II})$ ion, showed the same trend against both E. coli and S. aureus, with a significant activity at $16 \mathrm{~h}$ and a strong activity after $20 \mathrm{~h}$. Complex 1 showed the lowest activity among $1-4$, achieving only a significant activity after $24 \mathrm{~h}$. 


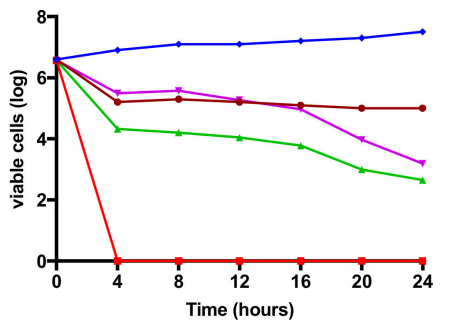

(a)

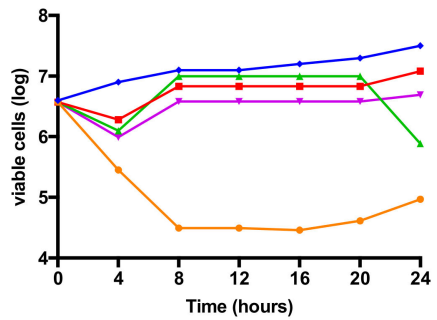

(c)

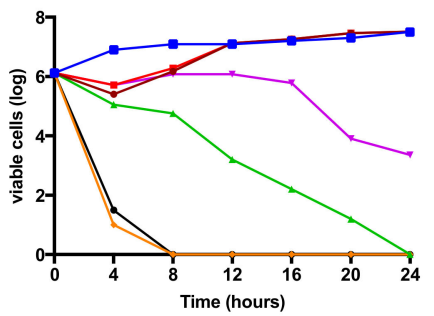

(e)
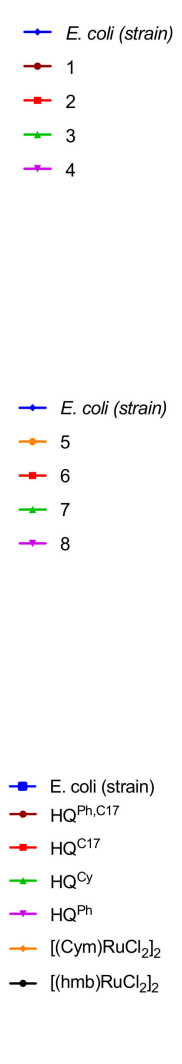

)

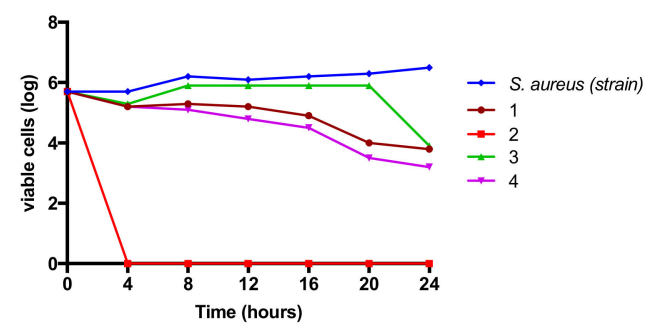

(b)

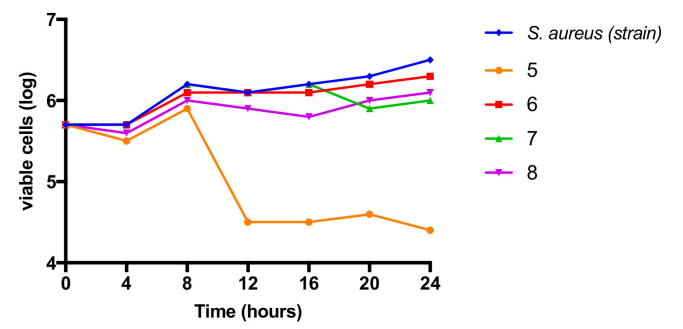

(d)

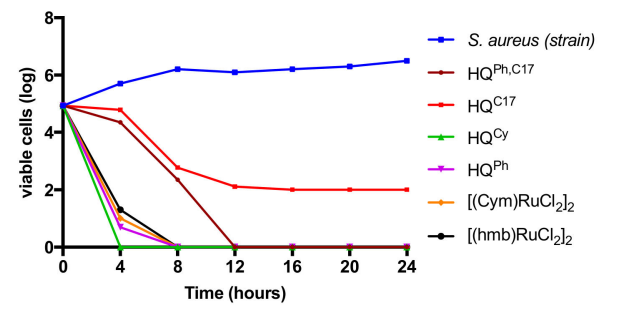

(f)

Figure 1. Time-kill kinetics assays with complexes 1-4 (a) and (b), complexes 5-8 (c) and (d), and proligands $\mathrm{HQ}^{\mathrm{R}}$ and the metal precursors $\left[(\mathrm{cym}) \mathrm{RuCl}_{2}\right]_{2}$ and $\left[(\mathrm{hmb}) \mathrm{RuCl}_{2}\right]_{2}(\mathbf{e})$ and (f).

Complexes 5-8, that contain $\mathrm{Q}^{\mathrm{R}}$ ligands bearing a phenyl or a cyclohexyl group on the acyl moiety, were also evaluated with complex 5 showing the highest activity against both E. coli and S. aureus, i.e., exhibiting a significant activity at $8 \mathrm{~h}$ against $E$. coli and at $24 \mathrm{~h}$ against $S$. aureus. Complex 7 displays a significant activity (1-3 log reduction) against $S$. aureus. The other complexes (6 and 8$)$ showed negligible antibacterial activity (Figure 1c,d).

Proligands $\mathrm{HQ}^{\mathrm{R}}$ showed a different effectiveness towards E. coli and S. aureus relative to the complexes. They all showed a strong antibacterial activity ( $>3 \log$ unit reduction) against $S$. aureus after $8 \mathrm{~h}$ (Figure 1f). In contrast, E. coli inhibition was only observed for proligands $\mathrm{HQ}^{\mathrm{Cy}}$ and $\mathrm{HQ}^{\mathrm{Ph}}$, with some differences. Proligands $\mathrm{HQ}^{\mathrm{C} 17}$ and $\mathrm{HQ}^{\mathrm{Ph}, \mathrm{C} 17}$ exerted a significant activity after $4 \mathrm{~h}$, after which their efficacy decreased with time (Figure 1e). Strong antibacterial activity was displayed by proligands $\mathrm{HQ}^{\mathrm{Cy}}$ and $\mathrm{HQ}^{\mathrm{Ph}}$ after only $4 \mathrm{~h}$, with an increase in efficacy over a period of $24 \mathrm{~h}$. To obtain some insights on the specific biological contribution of the organometallic precursors employed in $1-8,\left[(\mathrm{cym}) \mathrm{RuCl}_{2}\right]_{2}$ and $\left[(\mathrm{hmb}) \mathrm{RuCl}_{2}\right]_{2}$ were tested against E. coli and S. aureus (Figure $\left.1 \mathrm{e}, \mathrm{f}\right)$, and were found to display very strong antibacterial activity after $4 \mathrm{~h}$. Note that these precursors are highly reactive and are not suitable for immobilization in polystyrene. Concerning the potential mechanism for the antibacterial activity of our ruthenium complexes, we can related to the well-known chelation theory and, additionally, also liposolubility mainly in the case of complexes 1-4, which enhances their penetration into lipid membranes of the bacterial cell walls. This in turn will interrupt the respiratory processes of the cell, blocking the synthesis of proteins and growth of the bacteria [41-43].

\subsection{Amphipathic Behavior of Complexes 1-4}

By dissolving complex 1 (2 mg) in $\mathrm{MeOH}(10 \mathrm{~mL})$ and then adding $\mathrm{H}_{2} \mathrm{O}(10 \mathrm{~mL})$, we observed the formation of a dispersion that is not retained when filtered with 1-3 $\mu \mathrm{m}$ porosity filter paper. Therefore, 
the formation of micelles smaller than $1 \mu \mathrm{m}$ was hypothesized, due to the presence of the $C_{17}$ aliphatic chain in the $R_{2}$ position of the acylpyrazolone ligand, endowing the complex with surfactant-like properties, i.e., with the metal centre as the polar head and the long aliphatic chain representing the apolar moiety. As expected, the same amphipathic behaver was also observed with complexes $2-4$, which in common with 1 have a long aliphatic chain in their structure.

To verify the micellar nature of 1 the complex was dispersed in $\mathrm{MeOH} / \mathrm{H}_{2} \mathrm{O}$ on a polystyrene (PS) surface. The obtained material (sample A) was analysed by SEM and spherical aggregates with dimensions in the range 200 to $800 \mathrm{~nm}$ were observed (Figure 2a). The presence of complex 1 was confirmed by elemental analysis performed by Energy Dispersive X-ray (EDX), which highlights the presence of ruthenium (Figure $2 b$ ).

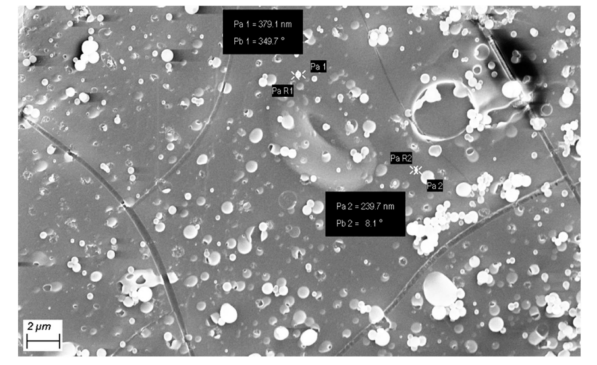

(a)

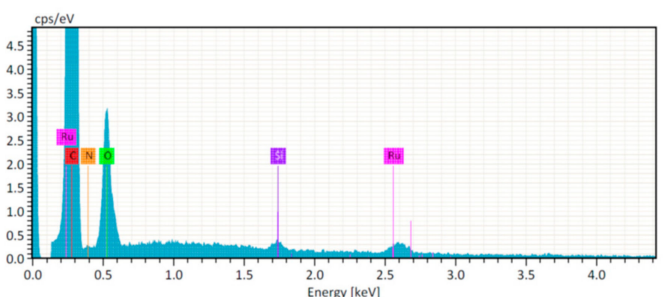

(b)

Figure 2. (a) SEM image of sample A obtained by deposition of 1 after evaporation of a micellar dispersion of 1 in $\mathrm{MeOH} / \mathrm{H}_{2} \mathrm{O}$ onto a polystyrene support, and (b) EDX spectrum of the spherical aggregates.

The SEM image, recorded by detecting the signal of the backscattered electrons, demonstrates how ruthenium, the heaviest element present in the sample, is positioned on the surface of micelles. Atoms with larger $\mathrm{Z}$ values usually give more intense signals, highlighted here by lighter areas in the image (Figure 2a). We hypothesize that the micelles assemble with the (arene)Ru(II) fragment of complex 1 on the periphery and the long aliphatic chains directed toward the center due to hydrophobic interactions, as depicted in Scheme 3.

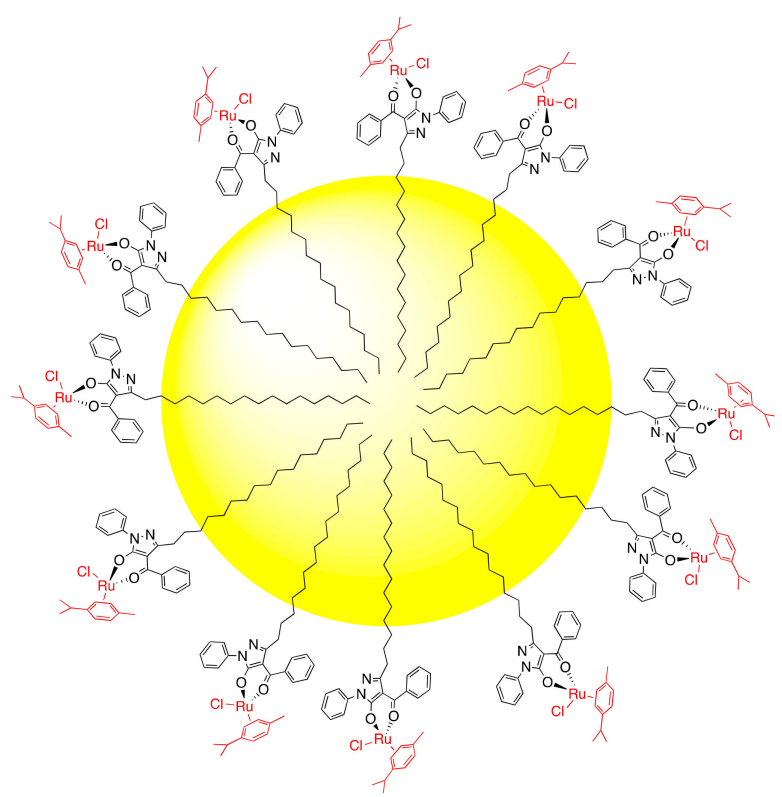

Scheme 3. Tentative structure of the nanometric micellar assembly composed of complex 1. 
Another material (sample B) was prepared by adding complex 1 directly to fused low-density polyethylene (LDPE) in 1:1000 w/w ratio, at a temperature of $110^{\circ} \mathrm{C}$, and then cooling the mixture to give a film with thickness $1 \mathrm{~mm}$. SEM analysis reveals aggregates of dimensions from 1 to $4 \mu \mathrm{m}$ spread over the LDPE surface (Figure 3).

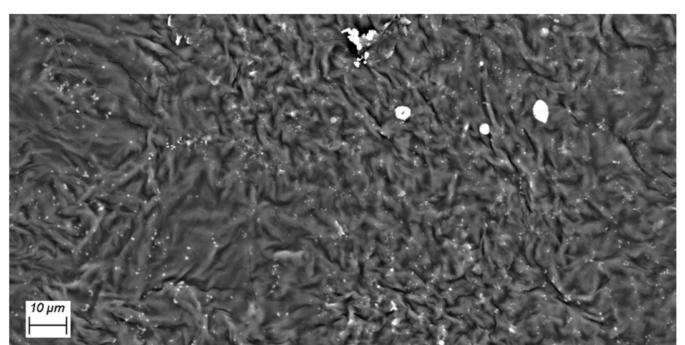

(a)

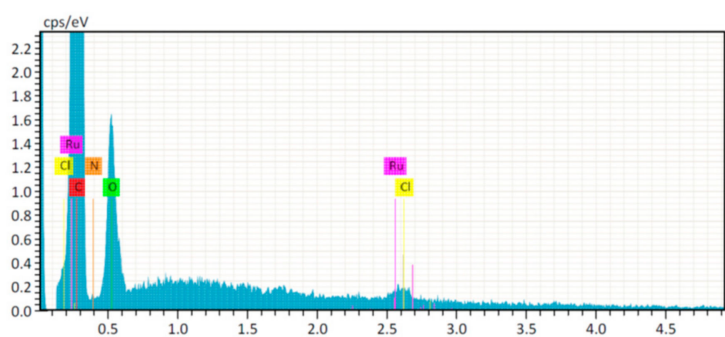

(b)

Figure 3. (a) SEM image of sample B obtained by direct addition of complex 1 to fused low-density polyethylene (LDPE) and (b) EDX spectrum of the aggregates.

The observed structure is possibly due to end-tethering of complex 1 with the (arene) $R u(I I)$ fragment oriented away from the LDPE surface and the apolar part of the aliphatic chain adhered to the LDPE surface through hydrophobic interactions (Scheme 4).

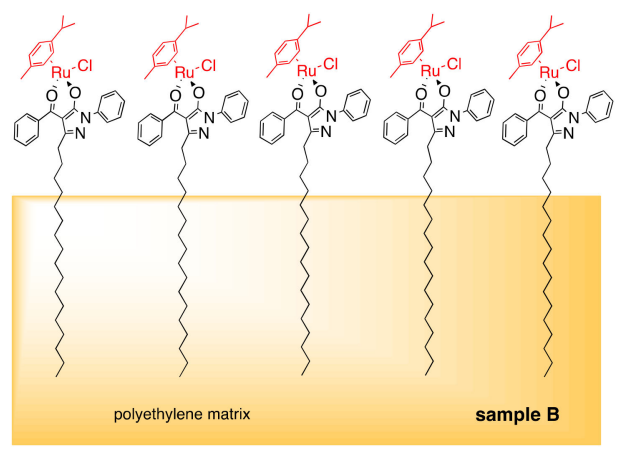

Scheme 4. Tentative structure of complex 1 immobilized on the surface of LDPE in sample B formed via hydrophobic interactions of long aliphatic chains with bulk polyethylene.

\subsection{Preparation of Samples PS1-PS4}

A common procedure to tether metal complexes on a PS surface is based on functionalization of the PS with organic fragments containing suitable donor atoms able to covalently interact and immobilize a metal-containing moiety, e.g., an amine moiety on a polystyrene-modified surface was used to immobilize Pd(II) acyclic diaminocarbene complexes [44,45]. With the aim of firmly tethering the long aliphatic chain present in complexes 1-4 to the PS surface through a simpler, faster and more economic non-covalent immobilization procedure, we used acetone as solvent capable to solubilize both PS and complexes 1-4. Thereby, a drop of acetone solution containing the $\mathrm{Ru}$ (II) complex (conc. $1.2 \times 10^{-4} \mathrm{M}$ ) was deposited on the surface of a square PS sample with dimensions $20 \mathrm{~mm} \times 20 \mathrm{~mm}$ and thickness $1.2 \mathrm{~mm}$ (Figure S8 in Supplementary ), in which the ruthenium complex and a solubilized thin polystyrene layer coexist, allowing the $C_{17}$ aliphatic chain in 1-4 to interact with the PS chains through hydrophobic interactions. Subsequent slow evaporation of the acetone solution favors the tethering of $\mathrm{Ru}$ (II) complexes on the PS surface, in a similar way to that proposed in Scheme 4. To remove any residual (arene) $\mathrm{Ru}(\mathrm{II})$ complex from the surface of PS not immobilized, samples PS1-PS4 were washed with methanol (as complexes 1-4 are soluble in this solvent whereas PS is insoluble). Complexes 5-8, do not possess amphipathic behavior, due to the absence of the long aliphatic chain in its structure, differently to complexes 1-4. Only the latter are in fact able to tether to polystyrene surface by our procedure of immobilization. For this reason, complexes 5-8 were not further investigated. 
The surfaces of samples PS1-PS4 were characterized by SEM, showing a homogeneous distribution of the complexes. As an example, Figure 4 shows the surface morphology of the PS2 sample. The dark furrows and light streaks with dimensions of 10-50 $\mu \mathrm{m}$ are observed, the latter containing the ruthenium compound 2, as confirmed by the elemental analysis (Figure 4c and Table 1) on the area framed by the red box in Figure $4 b$, where a magnification of a light streak is shown.

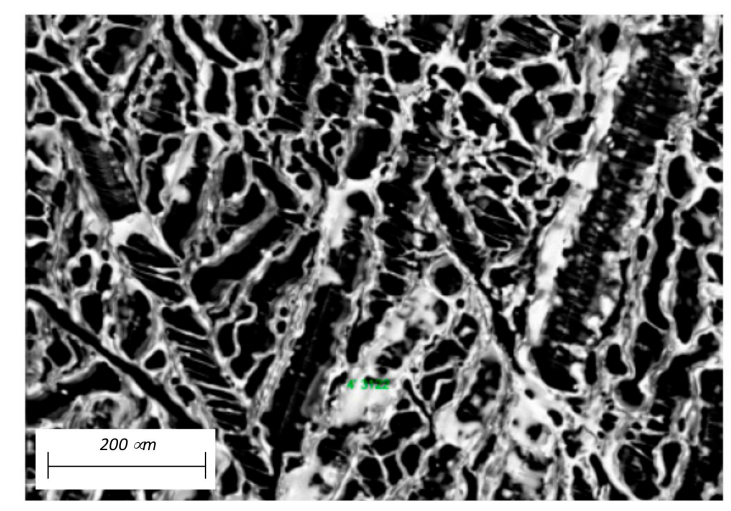

(a)

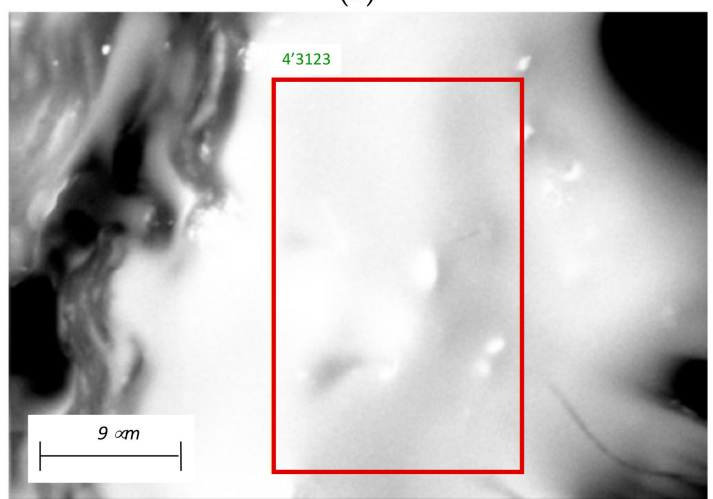

(b)

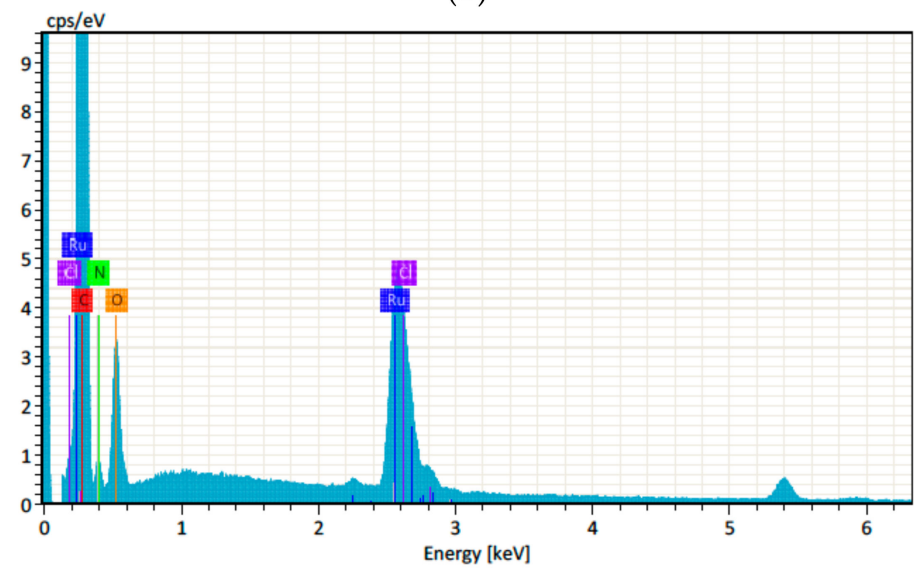

(c)

Figure 4. (a) Surface of PS2, (b) magnification of a light streak containing compound 2 and (c) EDX elemental analysis on the area framed by the red box in (b). 
Table 1. EDX elemental analysis data on the area 4'3123 framed by the red box in Figure 3b.

\begin{tabular}{cccccccc}
\hline Element & At. No. & Net & Mass [\%] & $\begin{array}{c}\text { Mass } \\
\text { Norm. [\%] }\end{array}$ & Atom & $\begin{array}{c}\text { Abs. Error } \\
{[\%](\mathbf{~ \sigma )})}\end{array}$ & $\begin{array}{c}\text { Rel. Error } \\
{[\%]}\end{array}$ \\
\hline Carbon & 6 & 329219 & 89.71 & 72.65 & 82.81 & 9.62 & 10.73 \\
Nitrogen & 7 & 4366 & 8.79 & 7.12 & 6.96 & 1.44 & 16.34 \\
Oxygen & 8 & 15301 & 11.79 & 9.55 & 8.17 & 1.59 & 13.45 \\
Chlorine & 17 & 24173 & 3.03 & 2.46 & 0.95 & 0.13 & 4.24 \\
Ruthenium & 44 & 52600 & 10.15 & 8.22 & 1.11 & 0.37 & 3.60 \\
& & Sum & $\mathbf{1 2 3 . 4 8}$ & $\mathbf{1 0 0 . 0 0}$ & $\mathbf{1 0 0 . 0 0}$ & & \\
\hline
\end{tabular}

Samples PS1-PS4 were also investigated by reflectance IR spectroscopy, with the absorptions due to the immobilized complexes being clearly identified, and essentially unchanged upon tethering (Figure 5).

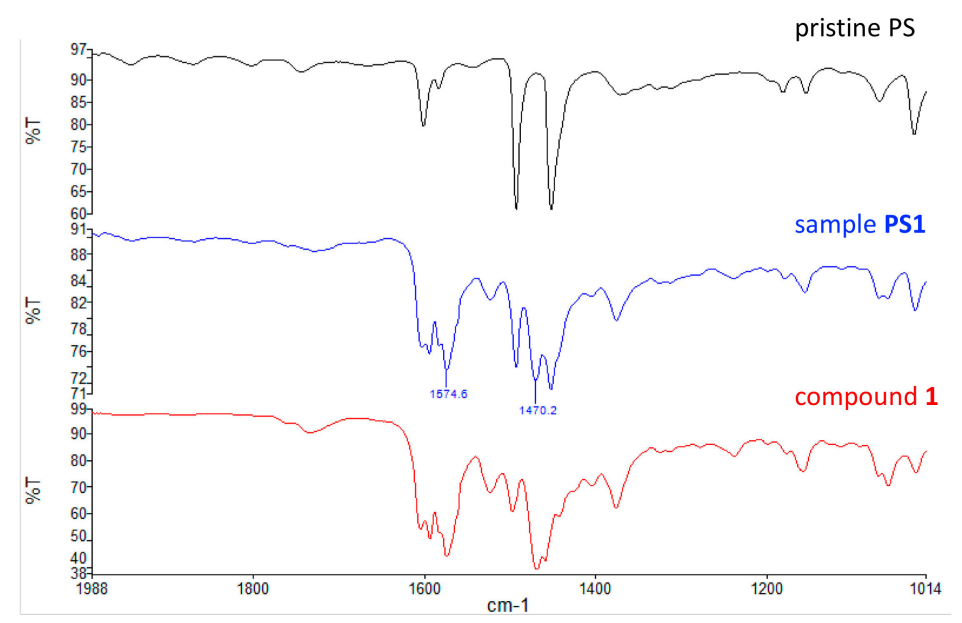

(a)

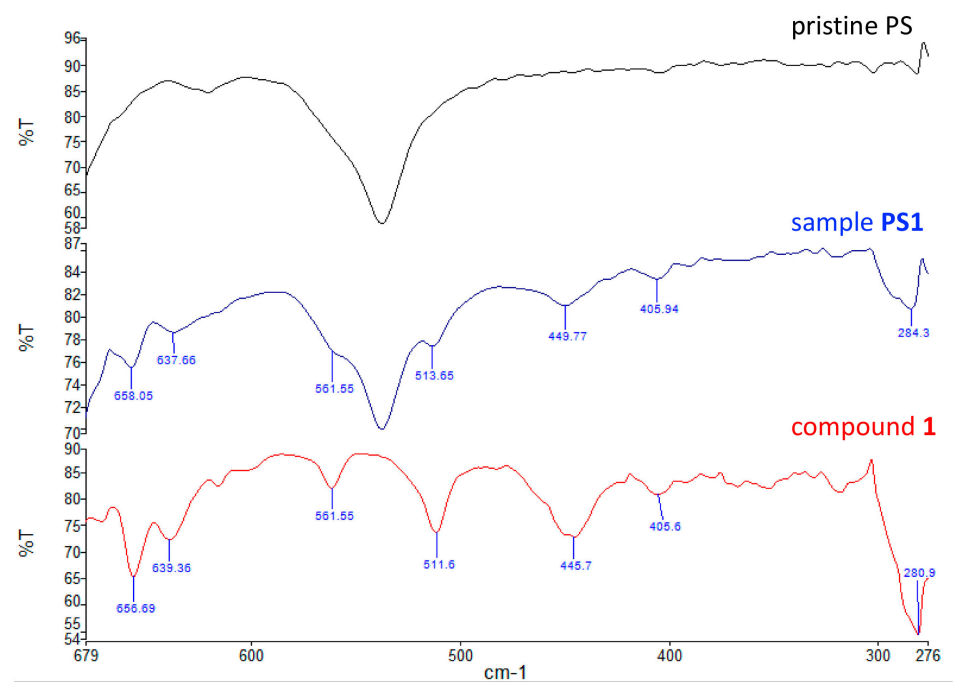

(b)

Figure 5. Comparison of the IR spectra of pristine PS, PS1 and compound 1 in (a) the medium region and (b) the far region. 


\subsection{Antibacterial Activity of PS1-PS4 According to ISO Standard}

To investigate the antibacterial activity of surfaces PS1-PS4 by contact, a standardized ISO test was carried out [46]. The results were elaborated according to the Japanese industrial standard (JIS) [47]. Figure 6 shows the results obtained against E. coli and S. aureus after $24 \mathrm{~h}$ of treatment, where the negative control is represented by pristine PS. PS1 showed the highest performance against $E$. coli, with a good antibacterial performance.

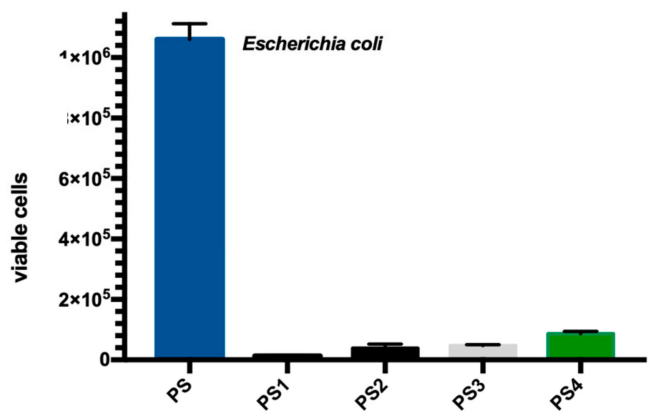

(a)

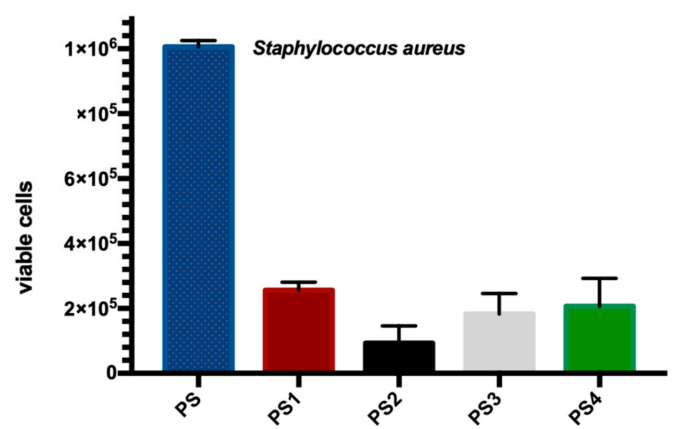

(b)

Figure 6. Antibacterial activity of PS1-PS4 against (a) E. coli and (b) S. aureus with respect to pristine PS, determined according to ISO standard and JIS [46,47].

Against $S$. aureus, instead, all samples showed a reduction of the antibacterial activity exhibiting the same behavior. The analysis of data highlighted that PS1, PS3 and PS4 achieved a Log reduction lower than 1, corresponding to a percentage of $68.4 \%$ to $90 \%$. Only the PS2 showed a medium antimicrobial performance with a percentage reduction of $90 \%$ to $99 \%$. Based on these trends, the influence of the acylpyrazolone ligand on the efficiency of ruthenium complexes 1-4 immobilized to the surface of PS, especially against $E$. coli, may be ascertained.

The aliphatic chain in the $\mathrm{Q}^{\mathrm{Ph}, \mathrm{C17}}$ ligand is pseudo-trans to the (arene)Ru(II) moiety, which could allow stronger tethering of the complexes to the PS surface and, hence, a good antibacterial activity through the arene-ruthenium moiety. In the $\mathrm{Q}^{\mathrm{C17}}$ ligand, the aliphatic chain is pseudo-cis to the ruthenium moiety, which could somewhat reduce its ability to exert the antibacterial activity (Scheme 5).

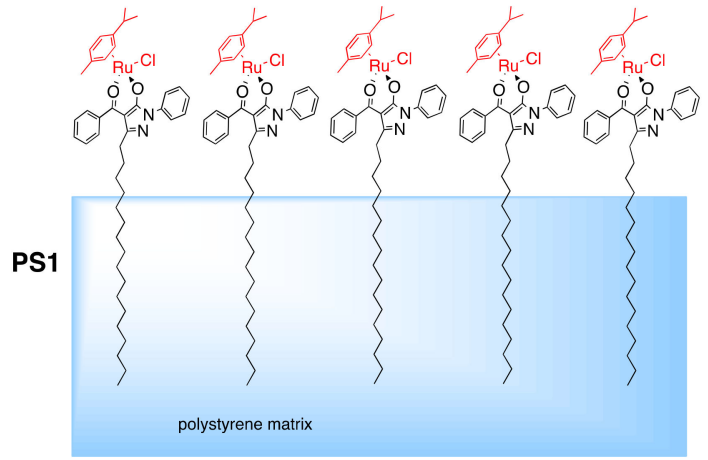

(a)

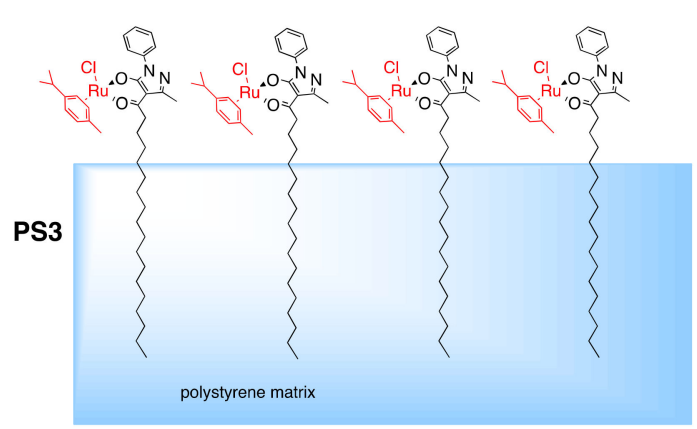

(b)

Scheme 5. Different orientations of tethered molecules of 1 and 3 with respect to the PS surface in PS1 (a) and PS3 (b).

\section{Materials and Methods}

Solvents were used as supplied or distilled using standard methods. All chemicals were purchased from Aldrich (Milwaukee, St. Louis, MO, USA) and used as received. The dimers $\left[\mathrm{Ru}(\operatorname{arene}) \mathrm{Cl}_{2}\right]_{2}$ $($ arene $=p$-cymeme $(\mathrm{cym})$ or hexamethylbenzene $(\mathrm{hmb}))$ were purchased from Aldrich. The proligands 
$\mathrm{HQ}^{\mathrm{R}}(\mathrm{R}=\mathrm{Ph}, \mathrm{Cy}$ or C17) were synthesized using literature methods [34]. Complexes 3-8 were synthesized using a procedure previously reported [31,32].

IR spectra were recorded on a Perkin-Elmer Frontier FT-IR instrument (PerkinElmer, Inc., Waltham, MA, USA). ${ }^{1} \mathrm{H}$ and ${ }^{13} \mathrm{C}$ NMR spectra were recorded on a 500Bruker Ascend (500 MHz for ${ }^{1} \mathrm{H}, 125 \mathrm{MHz}$ for ${ }^{13} \mathrm{C}$ ) instrument (Bruker Corporation, Billerica, MA, USA) operating at room temperature relative to TMS. Positive ion electrospray mass spectra (ESI-MS) were obtained on a Series 1100 MSI detector HP spectrometer (Agilent Technologies, Santa Clara, CA, USA), using methanol/dichloromethane as solvent for complexes $1-8$. Solutions $(3 \mathrm{mg} / \mathrm{mL}$ ) for electrospray ionization mass spectrometry (ESI-MS) were prepared using reagent-grade methanol. Melting points are uncorrected and were recorded on a STMP3 Stuart scientific instrument (Cole-Parmer, Stone, UK) TGA was performed on a PerkinElmer Pyris-1 thermogravimetric analyzer (PerkinElmer, Inc., Waltham, MA, USA), and the samples were heated from 30 to $850{ }^{\circ} \mathrm{C}$ at a heating rate of $10^{\circ} \mathrm{C} \mathrm{min}-1$ under a nitrogen atmosphere flow $(20 \mathrm{~mL}$ $\left.\mathrm{min}^{-1}\right)$. Samples for microanalysis were dried in vacuo to constant weight $\left(20^{\circ} \mathrm{C}\right.$, ca. 0.1 Torr $)$ and analysed on a Fisons Instruments 1108 CHNS-O elemental analyzer (Fisons Instruments, Ipswich, UK).

\subsection{Synthesis of Precursor 3-heptadecyl-1-phenyl-1H-pyrazol-5(4H)-one $H P^{P h, C 17}$}

Phenylhydrazine $(1.267 \mathrm{~g}, 11.5 \mathrm{mmol})$ was added to a methanol solution $(100 \mathrm{~mL})$ of ethyl stearoylacetate $(4.070 \mathrm{~g}, 11.5 \mathrm{mmol})$ in a $250 \mathrm{~mL}$ flask. The mixture was stirred at reflux for $12 \mathrm{~h}$, the solvent removed on a rotary evaporator and a brown oily product washed with diethyl ether $(20 \mathrm{~mL})$. A solid red-brown powder slowly formed. After filtration, the red-brown powder was dried in vacuo to constant weight and shown to be 3-heptadecyl-1-phenyl-1H-pyrazol-5(4H)-one (4.309 g, $10.81 \mathrm{mmol}, 94 \%$ yield). The compound is soluble in chlorinated solvents, acetone, DMF, diethyl ether and $n$-hexane diethyl ether and $n$-hexane, slightly soluble in hot ethanol and acetonitrile and insoluble in methanol and water. Mp: $64-65^{\circ} \mathrm{C}$. Anal. Calcd for $\mathrm{C}_{26} \mathrm{H}_{42} \mathrm{~N}_{2} \mathrm{O}$ (MW 398.62): C, 78.34; $\mathrm{H}, 10.62$; N, 7.03\%. Found: C, 78.04; H, 10.60; N, 6.95\%. IR ( $\left.\mathrm{cm}^{-1}\right)$ : 3049w, 2917vs, 2850s, 1615s, 1594m, 1566s, 1499s, 1470m, 1408m, 1355m, 1309m, 1151w, 1013w, 898w, 798m, 753vs, 718m, 688s, 664sh, 610m, 556w, 498m, 441w, 405w, 328w, 309m, 270w. ${ }^{1} \mathrm{H}$ NMR ( $\left.\mathrm{CDCl}_{3}, 298 \mathrm{~K}\right): \delta 0.90 \mathrm{t}, 1.28 \mathrm{br}, 1.45 \mathrm{br}, 1.76 \mathrm{br}, 2.64 \mathrm{br}$, $\left.2.73 \mathrm{t}\left(35 \mathrm{H}, 3-\left(\mathrm{CH}_{2}\right){ }_{16} \mathrm{CH}_{3}\right), 2.38 \mathrm{~s}\left(2 \mathrm{H}, 4-\mathrm{CH}_{2}\right), 7.18 \mathrm{t}, 7.41 \mathrm{t}, 7.96 \mathrm{~d}\left(5 \mathrm{H}, \mathrm{H}_{\text {arom }}\right) .{ }^{13} \mathrm{C}^{1} \mathrm{H}\right\} \mathrm{NMR}\left(\mathrm{CDCl}_{3}\right.$, $298 \mathrm{~K}): \delta 14.1 \mathrm{~s}, 22.7 \mathrm{~s}, 29.3,29.5 \mathrm{br}, 29.7 \mathrm{br}\left(\mathrm{C}_{17} \mathrm{H}_{35}\right.$ of $\left.\mathrm{HP}^{\mathrm{C} 17, \mathrm{Ph}}\right), 32.0 \mathrm{~s}(\mathrm{C} 4), 118.7,119.3 \mathrm{~s}, 119.6 \mathrm{~s}, 128.8 \mathrm{~s}$, $128.9 \mathrm{~s}, 120.0 \mathrm{~s}, 129.1 \mathrm{~s}\left(\mathrm{C}_{\text {arom }}\right.$ of $\left.\mathrm{HP}^{\mathrm{C} 17}\right)$.

\subsection{Synthesis of Proligand (3-heptadecyl-5-hydroxy-1-phenyl-1H-pyrazol-4-yl)(phenyl)methanone $H^{P h, C 17}$}

3-Heptadecyl-1-phenyl-1H-pyrazol-5 $(4 \mathrm{H})$-one $(1.0 \mathrm{~g}, 2.5 \mathrm{mmol})$ was placed in a flask equipped with a stirrer, separating funnel and a reflux condenser and dissolved in dry dioxane $(60 \mathrm{~mL})$ by warming. Calcium hydroxide $(0.39 \mathrm{~g}, 5.02 \mathrm{mmol})$ and then benzoyl chloride $(0.36 \mathrm{~g}, 2.5 \mathrm{mmol})$ were added, the latter dropwise over $10 \mathrm{~min}$. The mixture was heated to reflux overnight and then poured into $\mathrm{HCl} 2 \mathrm{~N}(20 \mathrm{~mL})$ to decompose the calcium complex. The resulting clear solution was heated to reduce the volume to one half, then dichloromethane $(10 \mathrm{~mL})$ was added and two phases formed. The organic phase, separated from the aqueous phase, was evaporated under reduced pressure to give a light brown solid, which was recrystallized from diethyl ether, dried to constant weight and shown to be 3-heptadecyl-5-hydroxy-1-phenyl-1H-pyrazol-4-yl)(phenyl)methanone (1.14 g, $2.27 \mathrm{mmol}, 90 \%$ yield). The compound is soluble in chlorinated solvents, acetone, DMF, diethyl ether and $n$-hexane, slightly soluble in hot ethanol. Mp: $47-49^{\circ} \mathrm{C}$. IR $\left(\mathrm{cm}^{-1}\right)$ : 3031w, 2921vs, 2852s, 1599s, 1547vs, $1499 \mathrm{~s}$, 1458s, 1377m, 1304w, 1291w, 12189w, 1155w, 1069w, 1025w, 1001w, 949m, 907w, 836w, 755vs, 698vs, 689vs, 667w, 636s, 617w, 538m, 508m, 458w, 412m, 377w, 348w, 326w, 289m, 270w. Anal. Calcd for $\mathrm{C}_{33} \mathrm{H}_{46} \mathrm{~N}_{2} \mathrm{O}_{2}$ (MW 502.73): C, 78.84; $\mathrm{H}, 9.22 ; \mathrm{N}, 5.57 \%$. Found: $\mathrm{C}, 78.26 ; \mathrm{H}, 9.18 ; \mathrm{N}, 5.41 \% .{ }^{1} \mathrm{H}$ NMR $\left(\mathrm{CDCl}_{3}, 298 \mathrm{~K}\right): \delta 0.90 \mathrm{t}, 1.07 \mathrm{br}, 1.76 \mathrm{br}, 2.06 \mathrm{br}, 2.49 \mathrm{t}\left(35 \mathrm{H}, 3-\left(\mathrm{CH}_{2}\right)_{16} \mathrm{CH}_{3}\right), 7.33 \mathrm{t}, 7.50 \mathrm{t}, 7.54 \mathrm{t}, 7.60 \mathrm{~m}, 7.66 \mathrm{~d}$, 7.91d $\left(10 \mathrm{H}, \mathrm{H}_{\text {arom }}\right) .{ }^{13} \mathrm{C}\left\{{ }^{1} \mathrm{H}\right\} \mathrm{NMR}\left(\mathrm{CDCl}_{3}, 298 \mathrm{~K}\right): \delta 14.1 \mathrm{~s}, 22.7 \mathrm{~s}, 28.5 \mathrm{~s}, 29.0,29.1 \mathrm{~s}, 29.2 \mathrm{~s}, 29.3 \mathrm{~s}, 29.4 \mathrm{~s}$, 29.5s, 29.6s, 29.7s, 29.8, 31.9s, $\left(C_{17} \mathrm{H}_{35}\right.$ of $\left.\mathrm{HQ}^{\mathrm{C} 17, \mathrm{Ph}}\right), 103.0 \mathrm{~s}(C 4), 120.1,126.6 \mathrm{~s}, 127.5 \mathrm{~s}, 128.4 \mathrm{~s}, 129.1 \mathrm{~s}$, $131.7 \mathrm{~s}, 137.4 \mathrm{~s}, 130.0 \mathrm{~s}\left(\mathrm{C}_{\mathrm{arom}}\right.$ of $\left.\mathrm{HQ}^{\mathrm{C} 17}\right)$, 152.3s (C3), 161.6s (C5), 192.2s (CO). 


\subsection{Synthesis of Complex [(Cym)Ru( $\left.\left.Q^{P h, C 17}\right) C l\right](1)$}

To the proligand $\mathrm{HQ}^{\mathrm{Ph}, \mathrm{C} 17}(166.0 \mathrm{mg}, 0.33 \mathrm{mmol})$ dissolved in methanol $(20 \mathrm{~mL}), \mathrm{KOH}(18.5 \mathrm{mg}$, $0.33 \mathrm{mmol}$ ) was added. The mixture was stirred for $1 \mathrm{~h}$ at room temperature, and then $\left[(\mathrm{cym}) \mathrm{RuCl}_{2}\right]_{2}$ $(100.0 \mathrm{mg}, 0.165 \mathrm{mmol})$ was added. The resulting solution was stirred under reflux for $24 \mathrm{~h}$. The solvent was removed under reduced pressure, and dichloromethane $(10 \mathrm{~mL})$ was added; the mixture was filtered to remove potassium chloride. The solution was left to evaporate at r.t., affording a brown-red viscous oil ( $224.3 \mathrm{mg}, 0.29 \mathrm{mmol}$, yield $88 \%$ ) that is soluble in methanol, ethanol, acetone, acetonitrile, DMSO, DMF, diethyl ether, n-hexane, and chlorinated solvents. Anal. Calcd for $\mathrm{C}_{43} \mathrm{H}_{59} \mathrm{ClN}_{2} \mathrm{O}_{2} \mathrm{Ru}$ (MW 772.5): C, 66.86; H, 7.70; N, 3.63\%. Found: C, 67.20; H, 7.86; N, 3.75\%. IR $\left(\mathrm{cm}^{-1}\right)$ : 3052w $v\left(\mathrm{C}-\mathrm{H}_{\text {arom }}\right) ; 2921 \mathrm{~s} 2851 \mathrm{~m} v\left(\mathrm{C}-\mathrm{H}_{\text {aliph }}\right), 1604 \mathrm{~s}, 1593 \mathrm{~s}, 1573 \mathrm{vs}, 1523 \mathrm{~m} v(\mathrm{C}=\mathrm{O}) ; 1496 \mathrm{~m}, 1468 \mathrm{vs}, 1375 \mathrm{~m}$, $v(\mathrm{C}=\mathrm{C}, \mathrm{C}=\mathrm{N}), 690 \mathrm{~s}, 656 \mathrm{~s}, 639 \mathrm{~m}, 562 \mathrm{w}, 512 \mathrm{~m}, 445 \mathrm{~m} v(\mathrm{Ru}-\mathrm{O}), 281 \mathrm{~s} v(\mathrm{Ru}-\mathrm{Cl}) .{ }^{1} \mathrm{H} \mathrm{NMR}\left(\mathrm{CDCl}_{3}, 298\right.$ $\mathrm{K}): \delta 0.90 \mathrm{t}, 1.01 \mathrm{~m}, 1.28 \mathrm{~m}, 2.49 \mathrm{t}\left(35 \mathrm{H}, 3-\left(\mathrm{CH}_{2}\right)_{16} \mathrm{CH}_{3}\right.$ of $\left.\mathrm{Q}^{\mathrm{Ph}, \mathrm{C17}}\right), 1.38 \mathrm{~d}\left(6 \mathrm{H}, \mathrm{CH}_{3}-\mathrm{C}_{6} \mathrm{H}_{4}-\mathrm{CH}\left(\mathrm{CH}_{3}\right)_{2}\right)$, $2.18 \mathrm{~s}\left(3 \mathrm{H}, \mathrm{CH}_{3}-\mathrm{C}_{6} \mathrm{H}_{4}-\mathrm{CH}\left(\mathrm{CH}_{3}\right)_{2}\right), 2.46 \mathrm{~m}\left(1 \mathrm{H}, \mathrm{CH}_{3}-\mathrm{C}_{6} \mathrm{H}_{4}-\mathrm{CH}\left(\mathrm{CH}_{3}\right)_{2}\right), 5.32 \mathrm{t}, 5.35 \mathrm{~d}, 5.49 \mathrm{~d}, 5.50 \mathrm{t}(4 \mathrm{H}$, $\left.\mathrm{CH}_{3}-\mathrm{C}_{6} \mathrm{H}_{4}-\mathrm{CH}\left(\mathrm{CH}_{3}\right)_{2}\right), 7.42 \mathrm{t}, 7.45 \mathrm{t}, 7.48 \mathrm{t}, 7.63 \mathrm{t}, 7.92 \mathrm{~d}, 7.99 \mathrm{~d}\left(10 \mathrm{H}, \mathrm{H}_{\text {arom }}\right.$ of $\left.\mathrm{Q}^{\mathrm{Ph}, \mathrm{C} 17}\right) .{ }^{13} \mathrm{C} \mathrm{NMR}$ $(\mathrm{CDCl} 3,298 \mathrm{~K}): \delta 18.0 \mathrm{~s}\left(\mathrm{CH}_{3}-\mathrm{C}_{6} \mathrm{H}_{4}-\mathrm{CH}\left(\mathrm{CH}_{3}\right)_{2}\right), 22.3 \mathrm{~s}, 22.4\left(\mathrm{CH}_{3}-\mathrm{C}_{6} \mathrm{H}_{4}-\mathrm{CH}\left(\mathrm{CH}_{3}\right)_{2}\right), 14.4 \mathrm{~s}, 18.9 \mathrm{~s}, 22.4 \mathrm{~s}$, $22.1 \mathrm{~s}, 22.7 \mathrm{~s}, 28.3 \mathrm{~s}, 28.5 \mathrm{~s}, 29.1 \mathrm{~s}, 29.2 \mathrm{~s}, 29.3 \mathrm{~s}, 29.4 \mathrm{~s}, 29.5 \mathrm{~s}, 29.6 \mathrm{~s}, 29.7 \mathrm{~s}, 31.9 \mathrm{~s},\left(C_{17} \mathrm{H}_{35}\right.$ of $\left.\mathrm{Q}^{\mathrm{C} 17, \mathrm{Ph}}\right), 30.8 \mathrm{~s}$ $\left(\mathrm{CH}_{3}-\mathrm{C}_{6} \mathrm{H}_{4}-\mathrm{CH}\left(\mathrm{CH}_{3}\right)_{2}\right), 79.0 \mathrm{~s}, 79.1 \mathrm{~s}, 80.5 \mathrm{~s}, 81.3 \mathrm{~s}, 82.3 \mathrm{~s}, 82.4 \mathrm{~s}, 96.6 \mathrm{~s}, 99.4 \mathrm{~s}\left(\mathrm{CH}_{3}-\mathrm{C}_{6} \mathrm{H}_{4}-\mathrm{CH}\left(\mathrm{CH}_{3}\right)_{2}\right)$, 105.7s (C4), 121.0s, 125.2s, 127.7s, 128.0s, 128.4s, 130.3s, 138.7s, 139.0s ( $C_{\text {arom }}$ of $\left.\mathrm{Q}^{\mathrm{C} 17}\right), 153.1 \mathrm{~s}(\mathrm{C} 3)$, 163.7s (C5), 188.0s (CO). ESI-MS (+) $\left(\mathrm{CH}_{3} \mathrm{OH}\right)\left(\mathrm{m} / \mathrm{z} \text {, relative intensity \%): } 737 \text { [100] [(cym) } \mathrm{Ru}\left(\mathrm{Q}^{\mathrm{Ph}, \mathrm{C} 17}\right)\right]^{+}$. TGA (mg\% vs. ${ }^{\circ} \mathrm{C}$ ): heating from 30 to $850{ }^{\circ} \mathrm{C}$ with a speed of $10^{\circ} \mathrm{C} / \mathrm{min}$; from 180 to $850{ }^{\circ} \mathrm{C}$ progressive loss of due to decomposition of the complex, with a final residual of $9.0 \%$ weight.

\subsection{Synthesis of Complex [(Hmb)Ru( $\left.\left.Q^{P h, C 17}\right) \mathrm{Cl}\right]$ (2)}

Complex 2 was prepared similarly to 1 by using $\mathrm{HQ}^{\mathrm{Ph}, \mathrm{C} 17}(166.0 \mathrm{mg}, 0.33 \mathrm{mmol}), \mathrm{KOH}(18.5 \mathrm{mg}$, $0.33 \mathrm{mmol})$ and $\left[(\mathrm{hmb}) \mathrm{RuCl}_{2}\right]_{2}(110.0 \mathrm{mg}, 0.165 \mathrm{mmol})$, but in this case a brown-red solid powder was isolated (240.4 mg, $0.30 \mathrm{mmol}$, yield 91\%). The compound is soluble in acetone, $\mathrm{CHCl}_{3}, \mathrm{CH}_{2} \mathrm{Cl}_{2}, \mathrm{DMF}$, diethyl ether, methanol, ethanol and slightly soluble in acetonitrile. M.p. $139-141{ }^{\circ} \mathrm{C}$. Anal. Calcd for $\mathrm{C}_{45} \mathrm{H}_{63} \mathrm{ClN}_{2} \mathrm{O}_{2} \mathrm{Ru}$ (MW 800.5): 67.52; $\mathrm{H}, 7.93 ; \mathrm{N}, 3.50 \%$. Found: $\mathrm{C}, 67.31 ; \mathrm{H}, 8.04 ; \mathrm{N}, 3.45 \%$. IR $\left(\mathrm{cm}^{-1}\right)$ : $3046 \mathrm{w} v\left(\mathrm{C}-\mathrm{H}_{\text {arom }}\right) ; 2921 \mathrm{~s}, 2850 \mathrm{~m} v\left(\mathrm{C}-\mathrm{H}_{\text {aliph }}\right), 1604 \mathrm{~s}, 1593 \mathrm{~s}, 1583 \mathrm{vs}, 1574 \mathrm{vs}, 1525 \mathrm{~m} v(\mathrm{C}=\mathrm{O}) ; 1495 \mathrm{~m}$, $1469 v s, 1460 \mathrm{~m}, 1373 \mathrm{~m}, 1308 \mathrm{w}, v(\mathrm{C}=\mathrm{C}, \mathrm{C}=\mathrm{N}), 690 \mathrm{vs}, 673 \mathrm{w}, 655 \mathrm{~s}, 634 \mathrm{w}, 617 \mathrm{w}, 560 \mathrm{~m}, 510 \mathrm{~m}, 462 \mathrm{~m}, 447 \mathrm{~s}$ $v(\mathrm{Ru}-\mathrm{O}), 402 \mathrm{w}, 385 \mathrm{w}, 333 \mathrm{w}, 287 \mathrm{~s}, 280 \mathrm{~s} v(\mathrm{Ru}-\mathrm{Cl}) .{ }^{1} \mathrm{H}$ NMR $\left(\mathrm{CDCl}_{3}, 298 \mathrm{~K}\right): \delta 0.90 \mathrm{t}, 1.01 \mathrm{~m}, 1.28 \mathrm{~m}, 2.49 \mathrm{t}$ $\left(35 \mathrm{H}, 3-\left(\mathrm{CH}_{2}\right)_{16} \mathrm{CH}_{3}\right.$ of $\left.\mathrm{Q}^{\mathrm{Ph}, \mathrm{C} 17}\right), 2.05 \mathrm{~s}, 2.11 \mathrm{~s}\left(18 \mathrm{H}, \mathrm{C}_{6}\left(\mathrm{CH}_{3}\right)_{6}\right), 7.42 \mathrm{t}, 7.49 \mathrm{t}, 7.53 \mathrm{t}, 7.66 \mathrm{t}, 7.91 \mathrm{~d}, 8.01 \mathrm{~d}(10 \mathrm{H}$, $H_{\text {arom }}$ of $\left.\mathrm{Q}^{\mathrm{Ph}, \mathrm{C} 17}\right) .{ }^{13} \mathrm{C} \mathrm{NMR}(\mathrm{CDCl} 3,298 \mathrm{~K}): \delta 15.4 \mathrm{~s}, 15.9 \mathrm{~s}\left(\mathrm{C}_{6}\left(\mathrm{CH}_{3}\right)_{6}\right), 14.1 \mathrm{~s}, 22.7 \mathrm{~s}, 28.3 \mathrm{~s}, 29.1 \mathrm{~s}, 29.2 \mathrm{~s}$, $29.3 \mathrm{~s}, 29.4 \mathrm{~s}, 29.5 \mathrm{~s}, 29.6 \mathrm{~s}, 29.7 \mathrm{~s}, 31.9 \mathrm{~s},\left(\mathrm{C}_{17} \mathrm{H}_{35}\right.$ of $\left.\mathrm{Q}^{\mathrm{C} 17, \mathrm{Ph}}\right), 89.6 \mathrm{~s}, 89.7 \mathrm{~s}\left(\mathrm{C}_{6}\left(\mathrm{CH}_{3}\right)_{6}\right), 105.3 \mathrm{~s}(\mathrm{C} 4), 120.8 \mathrm{~s}$, $124.8 \mathrm{~s}, 127.6 \mathrm{~s}, 127.9 \mathrm{~s}, 128.3 \mathrm{~s}, 130.1 \mathrm{~s}, 138.9 \mathrm{~s}, 139.8 \mathrm{~s}\left(\mathrm{C}_{\text {arom }}\right.$ of $\left.\mathrm{Q}^{\mathrm{C17}}\right), 152.8 \mathrm{~s}(\mathrm{C3}), 163.6 \mathrm{~s}(\mathrm{C} 5), 187.9 \mathrm{~s}(\mathrm{CO})$. ESI-MS (+) $\left(\mathrm{CH}_{3} \mathrm{OH}\right)\left(\mathrm{m} / \mathrm{z}\right.$, relative intensity \%): $765[100]\left[(\mathrm{hmb}) \mathrm{Ru}\left(\mathrm{Q}^{\mathrm{Ph}, \mathrm{Cl}}\right)\right]^{+}$. TGA $\left(\mathrm{mg} \% \mathrm{vs} .{ }^{\circ} \mathrm{C}\right)$ : heating from 30 to $850{ }^{\circ} \mathrm{C}$ with a speed of $10{ }^{\circ} \mathrm{C} / \mathrm{min}$; from 150 to $850{ }^{\circ} \mathrm{C}$ progressive loss of due to decomposition of the complex, with a final residual of $9.0 \%$ weight.

\subsection{Preparation of Samples PS1-PS4}

A thin film (2 drops) of an acetone solution of complex $1(0.5 \mathrm{mg}$ dissolved in $5 \mathrm{~mL}$ ) was deposited on a square surface of polystyrene of dimensions $20 \mathrm{~mm} \times 20 \mathrm{~mm}$ and $1.2 \mathrm{~mm}$ in thickness (Figure S8) and left to slowly evaporate at room temperature, affording a PS sample (sample PS1) in which the surface is coated with complex 1. Samples PS2-PS4 were prepared with the same procedure using complexes $2-4$, respectively. 


\subsection{Antibacterial Activity of Proligands $H Q^{R}$, of Complexes 1-8, and of Samples PS1-PS4}

\subsubsection{Time-Kill Kinetics Assay}

The antibacterial activity of proligands $\mathrm{HQ}^{\mathrm{R}}$, and (arene) $\mathrm{Ru}(\mathrm{II})$ complexes 1-8 was tested against Escherichia coli ATCC 25922 (VWR International PBI s.r.l., Milano, Italy) and S. aureus ATCC 25923 (VWR International PBI s.r.l., Milano, Italy), respectively Gram-negative and Gram-positive. Bacterial inoculum $\left(10^{6} \mathrm{CFU} \mathrm{mL} \mathrm{m}^{-1}\right)$, was obtained by a series dilution of an aerobically overnight culture in Tryptone Soya Broth (OXOID), as the growth medium. For each bacterium, $50 \mu \mathrm{L}$ of inoculum was added in the sterile test flask containing $5 \mathrm{~mL}$ of autoclaved physiological solution $(0.85 \% \mathrm{NaCl})$. The bacteria concentration was also checked by recording the absorbance at $600 \mathrm{~nm}$ with a UV-1601 CE spectrophotometer (SHIMADZU CORPERATION) using Tryptone Soya Broth as blank. $20 \mathrm{mg}$ of each powdered (arene)Ru(II) complex was then weighed and added to flask content. All flasks were kept on an IKA KS 130 BASIC platform shaker for speed of $160 \mathrm{rpm}$ and $24 \mathrm{~h}$. The concentration of 20 $\mathrm{mg}$ of ruthenium complex in $5 \mathrm{~mL}$ of culture was chosen because, based on preliminary tests, it was the best among three different concentrations $(50 \mathrm{mg} / 5 \mathrm{~mL}, 20 \mathrm{mg} / 5 \mathrm{~mL}$ and $5 \mathrm{mg} / 5 \mathrm{~mL}$ ) to obtain a good antibacterial activity with the lowest concentration of the antibacterial agent. To study the killing activity of proligands and complexes, periodic withdrawal of $5 \mu \mathrm{L}$ at times $0,4,8,12,16,20$ and $24 \mathrm{~h}$ was collected for each sample. To obtain the bacterial colony count, the supernatant fraction was diluted and included uniformly into Petri dishes containing Plate Count Agar (OXOID). Adopting the same procedure, a sample strain was used as control, and the number of viable cells counted was reported on the logarithmic scale.

\subsubsection{Antibacterial Activity According to ISO Standard}

The antibacterial activity by contact of samples PS1-PS4 was performed according to the ISO standard and the interpretation of the results elaborated according to the Japanese Industrial Standard (JIS) [46,47]. All tested square composites had dimensions of $20 \mathrm{~mm} \times 20 \mathrm{~mm}$ (1.2 $\mathrm{mm}$ in thickness) and were tested, in triplicate, against two strains: (Gram-positive) S. aureus ATCC 25923 and (Gram-negative) E. coli ATCC 25 922. Unloaded PS was used as the negative control. The appropriate culture medium was inoculated with the test microbes and cultivated for $24 \mathrm{~h}$ at $37^{\circ} \mathrm{C}$ under aerobic conditions, to achieve the concentration of $10^{6} \mathrm{CFU} / \mathrm{mL}$. Bacterial suspensions $(0.4 \mathrm{~mL})$ were inoculated onto the test surface and the inoculum was covered with a piece of low-density polyethylene film $(40 \times$ $40 \mathrm{~mm}$ ), gently pressed down to spread the inoculum to the edges. The Petri dishes containing the inoculated test specimens were incubated at $(35 \pm 1)^{\circ} \mathrm{C}$ and a relative humidity of not less than $90 \%$ for $24 \pm 1 \mathrm{~h}$. After the incubation time, the inoculum was processed by adding $10 \mathrm{~mL}$ SCDLP broth (Soybean casein digest broth with lecithin and polyoxyethylene sorbitan monooleate). From SCDLP broth, tenfold serial dilutions were made in phosphate-buffered physiological saline (PBS-saline) and aliquots of $1 \mathrm{~mL}$ for each dilution were placed in Petri dishes, and $15 \mathrm{~mL}$ of plate count agar (PCA) was poured to disperse the bacteria. The inverted Petri dishes were incubated at $(35 \pm 1)^{\circ} \mathrm{C}$ for $48 \mathrm{~h}$. After incubation, the numbers of colonies in the Petri dishes were counted. The numbers of bacteria surviving on the specimens tested were compared to the number of colonies present on the negative controls. The antibacterial activity (R) was determined according to the Japanese industrial standard [47] based on the following rating: no antimicrobial activity $\leq 0.5 \log$ microbial growth reduction; slight antimicrobial activity $=0.5-1.0 \mathrm{log}$ microbial growth reduction; significant antimicrobial activity $>1$ to $\leq 3 \log$ microbial growth reduction; strong antimicrobial activity $>3 \log$ microbial growth reduction.

\section{Conclusions}

We reported new (arene)Ru(II) complexes of acylpyrazolone proligands, some with a long aliphatic chain, and tested their antibacterial activity against Gram+ and Gram- bacterial colonies. The complexes display from medium to high activity, mainly those with the appended hydrophobic 
chain. These complexes were tethered to LDPE and PS surfaces through simple procedures affording composite materials endowed with efficient antibacterial activity.

Supplementary Materials: The following are available online at http://www.mdpi.com/1996-1944/13/3/526/s1: IR, ${ }^{1} \mathrm{H}$ and ${ }^{13} \mathrm{C}$ NMR spectra of proligand $\mathrm{HQ}^{\mathrm{C} 17, \mathrm{Ph}}$, its precursor $\mathrm{HP}^{\mathrm{C} 17, \mathrm{Ph}}$ and complexes 1 and 2.

Author Contributions: Conceptualization, C.D.N. and F.M.; methodology, C.P. and I.G.; validation, R.P. and S.S.; formal analysis, S.S.; investigation, A.T.; resources, C.P.; data curation, C.P.; writing—original draft preparation, C.D.N.; writing-review and editing, F.M. and P.J.D.; visualization, R.P.; supervision, C.D.N. All authors have read and agreed to the published version of the manuscript.

Funding: This research received no external funding.

Acknowledgments: We thank the University of Camerino for financial support.

Conflicts of Interest: The authors declare no conflict of interest.

\section{References}

1. Alessio, E. Thirty Years of the Drug Candidate NAMI-A and the Myths in the Field of Ruthenium Anticancer Compounds: A Personal Perspective. Eur. J. Inorg. Chem. 2017, 2017, 1549-1560. [CrossRef]

2. Su, W.; Tang, Z.; Li, P. Development of Arene Ruthenium Antitumor Complexes. Mini Rev. Med. Chem. 2016, 16, 787-795. [CrossRef] [PubMed]

3. Abid, M.; Shamsi, F.; Azam, A. Ruthenium Complexes: An Emerging Ground to the Development of Metallopharmaceuticals for Cancer Therapy. Mini Rev. Med. Chem. 2016, 16, 772-786. [CrossRef] [PubMed]

4. Burris, H.A.; Bakewell, S.; Bendell, J.C.; Infante, J.; Jones, S.F.; Spigel, D.R.; Weiss, G.J.; Ramanathan, R.K.; Ogden, A.; Von Hoff, D. Safety and Activity of IT-139, a Ruthenium-Based Compound, in Patients with Advanced Solid Tumours: A First-in-Human, Open-Label, Dose-Escalation Phase I Study with Expansion Cohort. ESMO Open 2016, 1, e000154. [CrossRef] [PubMed]

5. Lentz, F.; Drescher, A.; Lindauer, A.; Henke, M.; Hilger, R.A.; Hartinger, C.G.; Scheulen, M.E.; Dittrich, C.; Keppler, B.K.; Jaehde, U. Pharmacokinetics of a Novel Anticancer Ruthenium Complex (KP1019, FFC14A) in a Phase I Dose-Escalation Study. Anticancer Drugs 2009, 20, 97-103. [CrossRef]

6. Leijen, S.; Burgers, S.A.; Baas, P.; Pluim, D.; Tibben, M.; van Werkhoven, E.; Alessio, E.; Sava, G.; Beijnen, J.H.; Schellens, J.H.M. Phase I/II Study with Ruthenium Compound NAMI-A and Gemcitabine in Patients with Non-Small Cell Lung Cancer after First Line Therapy. Investig. New Drugs 2015, 33, 201-214. [CrossRef]

7. Rademaker-Lakhai, J.M.; van den Bongard, D.; Pluim, D.; Beijnen, J.H.; Schellens, J.H.M. A Phase I and Pharmacological Study with Imidazolium-Trans-DMSO-Imidazole-Tetrachlororuthenate, a Novel Ruthenium Anticancer Agent. Clin. Cancer Res. 2004, 10, 3717-3727. [CrossRef]

8. Alessio, E.; Messori, L. The Deceptively Similar Ruthenium (III) Drug Candidates KP1019 and NAMI-A Have Different Actions. What Did We Learn in the Past 30 Years? Met. Dev. Action Anticancer Agents 2018, 18, 141.

9. Englinger, B.; Pirker, C.; Heffeter, P.; Terenzi, A.; Kowol, C.R.; Keppler, B.K.; Berger, W. Metal Drugs and the Anticancer Immune Response. Chem. Rev. 2019, 119, 1519-1624. [CrossRef]

10. Monro, S.; Colón, K.L.; Yin, H.; Roque, J.; Konda, P.; Gujar, S.; Thummel, R.P.; Lilge, L.; Cameron, C.G.; McFarland, S.A. Transition Metal Complexes and Photodynamic Therapy from a Tumor-Centered Approach: Challenges, Opportunities, and Highlights from the Development of TLD1433. Chem. Rev. 2019, 119, 797-828. [CrossRef]

11. Biersack, B. Anticancer Activity and Modes of Action of (Arene) Ruthenium (II) Complexes Coordinated to C-, N-, and O-Ligands. Mini Rev. Med. Chem. 2016, 16, 804-814. [CrossRef] [PubMed]

12. Zheng, K.; Wu, Q.; Ding, Y.; Mei, W. Arene Ruthenium (II) Complexes: The Promising Chemotherapeutic Agent in Inhibiting the Proliferation, Migration and Invasion. Mini Rev. Med. Chem. 2016, 16, 796-803. [CrossRef] [PubMed]

13. Nazarov, A.A.; Mendoza-Ferri, M.-G.; Hanif, M.; Keppler, B.K.; Dyson, P.J.; Hartinger, C.G. Understanding the Interactions of Diruthenium Anticancer Agents with Amino Acids. JBIC J. Biol. Inorg. Chem. 2018, 23, 1159-1164. [CrossRef] [PubMed]

14. Gambino, D.; Otero, L. Design of Prospective Antiparasitic Metal-Based Compounds Including Selected Organometallic Cores. Inorg. Chim. Acta 2018, 472, 58-75. [CrossRef] 
15. Allardyce, C.S.; Dyson, P.J.; Ellis, D.J.; Salter, P.A.; Scopelliti, R. Synthesis and Characterisation of Some Water Soluble Ruthenium (II)-Arene Complexes and an Investigation of Their Antibiotic and Antiviral Properties. J. Organomet. Chem. 2003, 668, 35-42. [CrossRef]

16. Li, F.; Collins, J.G.; Keene, F.R. Ruthenium Complexes as Antimicrobial Agents. Chem. Soc. Rev. 2015, 44, 2529-2542. [CrossRef]

17. Smith, N.A.; Zhang, P.; Greenough, S.E.; Horbury, M.D.; Clarkson, G.J.; McFeely, D.; Habtemariam, A.; Salassa, L.; Stavros, V.G.; Dowson, C.G. Combatting AMR: Photoactivatable Ruthenium (II)-Isoniazid Complex Exhibits Rapid Selective Antimycobacterial Activity. Chem. Sci. 2017, 8, 395-404. [CrossRef]

18. Laurent, Q.; Batchelor, L.K.; Dyson, P.J. Applying a Trojan Horse Strategy to Ruthenium Complexes in the Pursuit of Novel Antibacterial Agents. Organometallics 2018, 37, 915-923. [CrossRef]

19. Lagarón, J.M.; Ocio, M.J.; López-Rubio, A. Antimicrobial Polymers; John Wiley \& Sons: Hoboken, NJ, USA, 2011.

20. Muñoz-Bonilla, A.; Cerrada, M.L.; Fernández-García, M. CHAPTER 1. Introduction to Antimicrobial Polymeric Materials. In Polymeric Materials with Antimicrobial Activity: From Synthesis to Applications; Royal Society of Chemistry: London, UK, 2013; Volume 10, pp. 1-21.

21. Simbine, E.O.; Rodrigues, L.C.; Lapa-Guimarães, J.; Kamimura, E.S.; Corassin, C.H.; Oliveira, C.A.F. Application of Silver Nanoparticles in Food Packages: A Review. Food Sci. Technol. 2019. [CrossRef]

22. Chernousova, S.; Epple, M. Silver as Antibacterial Agent: Ion, Nanoparticle, and Metal. Angez. Chem. Int. Ed. 2013, 52, 1636-1653. [CrossRef]

23. Marchetti, F.; Palmucci, J.; Pettinari, C.; Pettinari, R.; Marangoni, M.; Ferraro, S.; Giovannetti, R.; Scuri, S.; Grappasonni, I.; Cocchioni, M.; et al. Preparation of Polyethylene Composites Containing Silver(I) Acylpyrazolonato Additives and SAR Investigation of Their Antibacterial Activity. ACS Appl. Mater. Interfaces 2016, 8, 29676-29687. [CrossRef] [PubMed]

24. Tăbăcaru, A.; Pettinari, C.; Marchetti, F.; Di Nicola, C.; Domasevitch, K.V.; Galli, S.; Masciocchi, N.; Scuri, S.; Grappasonni, I.; Cocchioni, M. Antibacterial Action of 4,4'-Bipyrazolyl-Based Silver(I) Coordination Polymers Embedded in PE Disks. Inorg. Chem. 2012, 51, 9775-9788. [CrossRef] [PubMed]

25. Marchetti, F.; Palmucci, J.; Pettinari, C.; Pettinari, R.; Condello, F.; Ferraro, S.; Marangoni, M.; Crispini, A.; Scuri, S.; Grappasonni, I.; et al. Novel Composite Plastics Containing Silver(I) Acylpyrazolonato Additives Display Potent Antimicrobial Activity by Contact. Chem. Eur. J. 2015, 21, 836-850. [CrossRef] [PubMed]

26. Pettinari, R.; Marchetti, F.; Condello, F.; Pettinari, C.; Lupidi, G.; Scopelliti, R.; Mukhopadhyay, S.; Riedel, T.; Dyson, P.J. Ruthenium(II)-Arene RAPTA Type Complexes Containing Curcumin and Bisdemethoxycurcumin Display Potent and Selective Anticancer Activity. Organometallics 2014, 33, 3709-3715. [CrossRef]

27. Pettinari, R.; Condello, F.; Marchetti, F.; Pettinari, C.; Bautista-Toledo, M.I.; Morales-Torres, S.; Dyson, P.J.; Maldonado-Hódar, F.J. Composite Materials Based on (Cymene)Ru(II) Curcumin Additives Loaded on Porous Carbon Adsorbents from Agricultural Residues Display Efficient Antibacterial Activity. ACS Appl. Bio Mater. 2018, 1, 153-159. [CrossRef]

28. Sultan, M.; El-Sharkawy, I.I.; Miyazaki, T.; Saha, B.B.; Koyama, S. An Overview of Solid Desiccant Dehumidification and Air Conditioning Systems. Renew. Sustain. Energy Rev. 2015, 46, 16-29. [CrossRef]

29. Pettinari, R.; Pettinari, C.; Marchetti, F.; Skelton, B.W.; White, A.H.; Bonfili, L.; Cuccioloni, M.; Mozzicafreddo, M.; Cecarini, V.; Angeletti, M.; et al. Arene-Ruthenium(II) Acylpyrazolonato Complexes: Apoptosis-Promoting Effects on Human Cancer Cells. J. Med. Chem. 2014, 57, 4532-4542. [CrossRef]

30. Caruso, F.; Monti, E.; Matthews, J.; Rossi, M.; Gariboldi, M.B.; Pettinari, C.; Pettinari, R.; Marchetti, F. Synthesis, Characterization, and Antitumor Activity of Water-Soluble (Arene)Ruthenium(II) Derivatives of 1,3-Dimethyl-4-Acylpyrazolon-5-Ato Ligands. First Example of Ru(Arene)(Ligand) Antitumor Species Involving Simultaneous Ru-N7(Guanine) Bonding and Lig. Inorg. Chem. 2014, 53, 3668-3677. [CrossRef]

31. Palmucci, J.; Marchetti, F.; Pettinari, R.; Pettinari, C.; Scopelliti, R.; Riedel, T.; Therrien, B.; Galindo, A.; Dyson, P.J. Synthesis, Structure, and Anticancer Activity of Arene-Ruthenium(II) Complexes with Acylpyrazolones Bearing Aliphatic Groups in the Acyl Moiety. Inorg. Chem. 2016, 55, 11770-11781. [CrossRef]

32. Marchetti, F.; Pettinari, R.; Di Nicola, C.; Pettinari, C.; Palmucci, J.; Scopelliti, R.; Riedel, T.; Therrien, B.; Galindo, A.; Dyson, P.J. Synthesis, Characterization and Cytotoxicity of Arene-Ruthenium(II) Complexes with Acylpyrazolones Functionalized with Aromatic Groups in the Acyl Moiety. Dalton Trans. 2018, 47, 868-878. [CrossRef] 
33. Marchetti, F.; Pettinari, R.; Pettinari, C. Recent Advances in Acylpyrazolone Metal Complexes and Their Potential Applications. Coord. Chem. Rev. 2015, 303, 1-31. [CrossRef]

34. Marchetti, F.; Pettinari, C.; Pettinari, R. Acylpyrazolone Ligands: Synthesis, Structures, Metal Coordination Chemistry and Applications. Coord. Chem. Rev. 2005, 249, 2909-2945. [CrossRef]

35. Pettinari, C.; Marchetti, F.; Drozdov, A. $\beta$-Diketones and Related Ligands. In Comprehensive Coordination Chemistry II; McCleverty, J.A., Meyer, T.J., Eds.; Elsevier: Amsterdam, The Netherlands, 2004; Volume 1, pp. 97-115.

36. Renfrew, A.K.; Juillerat-Jeanneret, L.; Dyson, P.J. Adding Diversity to Ruthenium (II)-Arene Anticancer (RAPTA) Compounds via Click Chemistry: The Influence of Hydrophobic Chains. J. Organomet. Chem. 2011, 696, 772-779. [CrossRef]

37. Casini, A.; Edafe, F.; Erlandsson, M.; Gonsalvi, L.; Ciancetta, A.; Re, N.; Ienco, A.; Messori, L.; Peruzzini, M.; Dyson, P.J. Rationalization of the Inhibition Activity of Structurally Related Organometallic Compounds against the Drug Target Cathepsin B by DFT. Dalton Trans. 2010, 39, 5556-5563. [CrossRef]

38. Wypych, G.; Polystyrene, P.S. Handbook of Polymers; ChemTec Publishing: Toronto, Canada, 2012; pp. 541-547.

39. Kurteva, V.B.; Petrova, M.A. Synthesis of 3-Methyl-4-(4-Methylbenzoyl)-1-Phenyl-Pyrazol-5-One: How To Avoid O-Acylation. J. Chem. Educ. 2015, 92, 382-384. [CrossRef]

40. Marchetti, F.; Pettinari, C.; Pettinari, R.; Cerquetella, A.; Cingolani, A.; Chan, E.J.; Kozawa, K.; Skelton, B.W.; White, A.H.; Wanke, R.; et al. Areneruthenium(II) 4-Acyl-5-Pyrazolonate Derivatives: Coordination Chemistry, Redox Properties, and Reactivity. Inorg. Chem. 2007, 46, 8245-8257. [CrossRef]

41. Thangadurai, T.D.; Natarajan, K. Antibacterial Activity of Ruthenium(II) Carbonyl Complexes Containing Tetradentate Schiff Bases. Transit. Met. Chem. 2002, 27, 485-489. [CrossRef]

42. Mehta, J.V.; Gajera, S.B.; Patel, M.N. Design, Synthesis and Biological Evaluation of Pyrazoline Nucleus Based Homoleptic Ru (III) Compounds. Medchemcomm 2016, 7, 1367-1380. [CrossRef]

43. Mehta, J.V.; Gajera, S.B.; Patel, M.N. Biological Applications of Pyrazoline-Based Half-Sandwich Ruthenium (III) Coordination Compounds. J. Biomol. Struct. Dyn. 2017, 35, 1599-1607. [CrossRef]

44. Mikhaylov, V.N.; Sorokoumov, V.N.; Korvinson, K.A.; Novikov, A.S.; Balova, I.A. Synthesis and Simple Immobilization of Palladium(II) Acyclic Diaminocarbene Complexes on Polystyrene Support as E Ffi Cient Catalysts for Sonogashira and Suzuki-Miyaura Cross-Coupling. Organometallics 2016, 35, 1684-1697. [CrossRef]

45. Mikhailov, V.N.; Korvinson, K.; Sorokoumov, V.N. Chiral Acyclic Diaminocarbene Complexes of Palladium (II) Immobilized on a Polymeric Support as Promising Catalysts of the Suzuki Reaction. Russ. J. Gen. Chem. 2016, 86, 2473-2476. [CrossRef]

46. British Standards Institution. International Standard ISO 22196: 2007. Plastics-Measurement of Antibacterial Activity on Plastics Surfaces, 1st ed.; BSI: London, UK, 2007.

47. Japanese Industrial Standard Community. Testing Method for Antibacterial Activity of Textiles: JIS L 1902; Japanese Standards Association: Tokyo, Japan, 2002.

(C) 2020 by the authors. Licensee MDPI, Basel, Switzerland. This article is an open access article distributed under the terms and conditions of the Creative Commons Attribution (CC BY) license (http://creativecommons.org/licenses/by/4.0/). 